\title{
Diminutives in child-directed speech supplement metric with distributional word segmentation cues
}

\author{
VERA KEMPE \\ University of Stirling, Stirling, Scotland \\ PATRICIA J. BROOKS \\ College of Staten Island and Graduate Center of City University of New York, New York \\ and \\ STEVEN GILLIS \\ University of Antwerp, Antwerp, The Netherlands
}

\begin{abstract}
In two experiments, we explored whether diminutives (e.g., birdie, Patty, bootie), which are characteristic of child-directed speech in many languages, aid word segmentation by regularizing stress patterns and word endings. In an implicit learning task, adult native speakers of English were exposed to a continuous stream of synthesized Dutch nonsense input comprising 300 randomized repetitions of six bisyllabic target nonwords. After exposure, the participants were given a forced choice recognition test to judge which strings had been present in the input. Experiment 1 demonstrated that English speakers used trochaic stress to isolate strings, despite being unfamiliar with Dutch phonotactics. Experiment 2 showed benefits from invariance introduced by affricates, which are typically found at onsets of final syllables in Dutch diminutives. Together, the results demonstrate that diminutives contain prosodic and distributional features that are beneficial for word segmentation.
\end{abstract}

Isolating words in continuous speech is a major challenge faced by language learners. Various informational sources - for example, rhythmic and prosodic patterns (e.g., Jusczyk, Houston, \& Newsome, 1999; Morgan, 1996; Morgan \& Saffran, 1995), utterance boundaries (Brent \& Siskind, 2001), phonotactic regularities (e.g., Mattys \& Jusczyk, 2001b), transitional probabilities between phonemes or syllables (e.g., Saffran, Aslin, \& Newport, 1996), and context- or position-sensitive allophony (e.g., Jusczyk, Hohne, \& Bauman, 1999; Mattys \& Jusczyk, 2001a) - have been shown to aid learners in word segmentation. As compared with adult-directed speech (ADS), child-directed speech (CDS) contains more acoustic cues to word boundaries due to exaggerated stress patterns (Fernald, 1989) and shorter utterances with longer and more frequent pauses. Computational studies have confirmed that CDS constitutes input for word segmentation models that is superior to that of ADS (Aslin, Woodward, LaMendola, \& Bever, 1996; Batchelder, 2002;

This research was supported by grants from PSC-CUNY and Language Learning: A Journal of Research in Language Studies. We thank Marc Swerts for help in synthesizing the stimuli and Claire Thomson for running the experiments. Correspondence should be addressed to V. Kempe, Department of Psychology, University of Stirling, Stirling FK9 4LA, Scotland (e-mail: vk2@stir.ac.uk).
Brent \& Cartwright, 1996; Christiansen, Allen, \& Seidenberg, 1998).

Jusczyk (1997) and Echols, Crowhurst, and Childers (1997) suggested yet another reason why CDS may be beneficial for word segmentation. They hypothesized "that many diminutive forms in English that are used in addressing infants have strong/weak patterns . . . (e.g., 'daddy,' 'mommy,' 'doggie,' 'cookie,' 'kitty,' etc.). Consequently, it is not implausible that infants in Englishspeaking environments might develop a bias for trochaic patterns" (Jusczyk, 1997, p. 108). Given that diminutives are pervasive in the CDS of many languages (Gillis, 1998; Jurafsky, 1996) and are often derived by adding unstressed suffixes to word stems, it is possible that stress regularization in CDS through diminutivization is a more general phenomenon. In Dutch, a language with lexical stress, diminutives make up about $20 \%-30 \%$ of all childdirected noun tokens (Gillis, 1997), which increases the frequency of stressed/unstressed nouns in CDS to 74\% of multisyllabic word types (Taelman \& Gillis, 2000). In Russian, approximately $45 \%$ of noun tokens in CDS are diminutives, as compared with only $3 \%$ in the ADS of the same Russian mothers (Brooks, Kempe, Fedorova, \& Mironova, 2002). Connectionist simulations of word boundary detection based on stress information of the 200 most frequent Russian nouns show superior performance when networks are trained on diminutive, rather 
than simplex, forms (Kempe, 2004), indicating that diminutivization leads to stress regularization. In Spanish, many words with atypical stress assignment (e.g., teléfono, "telephone") have regular penultimate stress when diminutivized (e.g., telefonito, "small telephone"). Across languages, stress regularization is a common effect of diminutivization.

Regularized stress patterns facilitate the use of a metrical segmentation strategy (Cutler, 1994; Cutler \& Norris, 1988), by which listeners rely on knowledge about predominant rhythmic patterns in their language to detect word boundaries. It has been shown that English stressed syllables are important cues for word onsets, which are utilized by infants and adults, both with phonotactically familiar (Echols et al., 1997; Jusczyk, Houston, \& Newsome, 1999) and with unfamiliar (Houston, Jusczyk, Kuijpers, Coolen, \& Cutler, 2000) language input.

Note that regularizing stress through diminutivization is inevitably confounded with another important word boundary cue: Because languages contain a limited number of diminutive suffixes, diminutivized nouns have similar endings. For example, daddy, mommy, doggie, cookie, and kitty all end in the same vowel. In languages with more complex diminutive derivations, the invariant segment can be even longer. For instance, Spanish diminutives end in -ito /ito/ or -ita /ita/, depending on gender, German diminutives end in -chen / $\chi ə n$ / or -lein /lajn/, Dutch diminutives end in -tje/tjə/ or one of its allomorphs, and Russian diminutives end in affixes such as -(ch)ik /(t f)ik/, -(ch) ka /(t J)ka/, or - (ch) ko /(t J)k $\mathrm{k} /,^{1}$ depending on gender, case, and number. ${ }^{2}$ This introduces a large degree of ending invariance, providing another word boundary cue.

Thus, diminutives provide two important segmentation cues: regularized stress and increased word ending invariance. Although the former has been studied empirically, albeit not in the context of diminutivization, the latter has not received any attention in word segmentation research. In this study, we investigated whether ending invariance facilitates segmentation over and above the effects of regular stress. We used Dutch, a language with highly productive diminutivization, for which the necessary speech synthesizing software was available. Experiment 1 confirmed that trochaic stress in unfamiliar language input aids English listeners in word segmentation, as was observed in Houston et al. (2000), and provides a baseline estimate of the advantage of trochaic stress over other stress patterns. In Experiment 2, we explored the effect of ending invariance on word segmentation by examining the contributions of consonant and vowel invariance, as found in Dutch diminutive affixes, over and above the effects of stress.

Using Dutch provides considerable ecological validity, because diminutivization is a much more productive derivation in Dutch than in English. Almost all Dutch concrete nouns can be diminutivized by adding the unstressed suffix -tje /t jə/, or its variants - etje /ot jə/, -pje /pjə/, -kje /kjə/, or -je/jə/, 3 to simplex nouns such as chair (stoel /stul/ > stoeltje /stultjə/), glass (glas /glas/ > glaasje /glasjə/), or window (raam /ram/ > raampje /rampjə/). In contrast, English allows diminutivization of only a small number of animate nouns (e.g., doggie), proper names (e.g., Stevie), and baby objects (e.g., bootie).

We utilized an incidental learning paradigm, originally developed for the study of transitional probabilities between phonemes (Saffran, Newport, Aslin, Tunick, \& Barrueco, 1997). Adult English speakers were presented with continuous speech consisting of repetitions of bisyllabic nonwords, synthesized to ensure equivalent levels of coarticulation between the syllables (both word internal and across word boundaries) and to eliminate other word boundary cues (e.g., pauses). Use of nonwords was necessary to avoid potential cognates with English and to manipulate stress patterns and ending invariance in a systematic way. After listening to the speech stream, the participants were given a forced choice task to determine whether there was better recognition of target strings over foils.

\section{EXPERIMENT 1}

The participants listened to an uninterrupted stream of Dutch bisyllabic nonwords with trochaic, iambic, or mixed stress patterns. Because English speakers tend to perceive stressed syllables as word onset cues, we predicted that exposure to trochaic stress in phonotactically novel input would facilitate their forming perceptual bisyllabic units and recognizing them as words, in comparison with input with other stress patterns.

\section{Method}

Participants. Seventy-two native speakers of English (44 women and 28 men; mean age, 24 years; range, 17-42 years) received course credit or $£ 4$ for participation. We pseudorandomly assigned 24 participants to each condition - stressed/unstressed, unstressed/ stressed, and mixed stress - with roughly equal numbers of women per condition.

Materials. We created six bisyllabic Dutch nonword targets that followed a CCVCCV pattern, ended in full vowels, and were not English cognates (see Appendix A). The targets were synthesized using the Dutch speech synthesizer CALIPSO (developed at IPO, University of Eindhoven), which allowed systematic manipulation of metric stress. A 6-min speech stream, comprising 100 repetitions of each target in random order, was repeated three times without pausing for a total duration of about $18 \mathrm{~min}$. Within each condition, we used three different randomizations. Two versions of the mixed condition were created in such a way that three strings were stressed/ unstressed in one version and unstressed/stressed in the other and vice versa, resulting in a nonrepetitive stress pattern. The assigned stress patterns were evidenced by syllable pitch peaks, which are one of the most salient acoustic indicators of Dutch metrical stress (Sluijter, 1995). The speech synthesizer also utilized other correlates of metrical stress, such as pitch differences, intensity, and vowel length.

To create foils, the syllables of the six targets were recombined so that first syllables followed second syllables. Whereas each target syllable sequence appeared 300 times during training, each foil syllable sequence appeared, on average, only 60 times during training, and with a stress pattern different from that of the targets. Test strings 
were resynthesized, minimizing pitch peak differences between the first and the second syllables to reduce metrical information. ${ }^{4}$

Procedure. The participants were given paper and colored pencils to create drawings, using a Spirograph game, consisting of plastic templates of different shapes and sizes. After 5 min of practice, they were instructed to create a drawing, being as creative as possible. While drawing, the participants were exposed to the 18-min speech stream over headphones and were told that this was done to study the effect of sound on artistic creativity.

Next, the participants were seated in front of a Macintosh computer and, over headphones, were presented with the 72 target-foil test pairs in randomized order. For each pair, they were asked to decide which string sounded more familiar and to press one of two buttons on the keyboard corresponding to the first or the second string. If they could not decide, they were encouraged to guess. Error rates were recorded.

\section{Results and Discussion}

Table 1 presents summary statistics for correct responses per condition. One-sample $t$ tests were performed to examine whether performance in each condition differed from chance $(50 \%)$. The participants performed above chance in the stressed/unstressed condition $[t(23)=$ $2.2, p<.05]$, confirming use of a metrical segmentation strategy with phonotactically unfamiliar input. The participants performed below chance in the unstressed/ stressed condition $[t(23)=-2.9, p<.01]$. To explore differences between conditions, percentages of correct responses were entered into a one-way analysis of variance (ANOVA) with condition (stressed/unstressed, unstressed/stressed, or mixed) as a between-subjects factor. The effect of condition was significant $[F(2,69)=$ $7.4, p<.01]$, accounting for $17.6 \%$ of the variance. Post hoc Scheffé tests revealed a significant difference between the stressed/unstressed and the unstressed/ stressed conditions $(p<.01)$, indicating that the participants segmented trochaic strings, but not iambic strings, out of the speech stream and that iambic string sequences were systematically missegmented as trochees.

These results, replicating Houston et al. (2000), indicate that English speakers, when exposed to phonotactically unfamiliar input, learn to detect stress regularities and to apply the metrical segmentation strategy on the basis of their preference for stressed syllables as word onset cues. Note that this is a consequence of incidental learning that has taken place during exposure, since the test stimuli were resynthesized as unstressed to avoid an a priori trochaic bias. The systematic missegmentation of iambic strings can be attributed to exclusive reliance on metrical stress and mirrors the missegmentation of iambic words ob-

Table 1

Mean Percentages of Correct Responses and Standard Deviations for Each Condition in Experiment 1

Stress Pattern of Targets

\begin{tabular}{lccccccc}
\hline \multicolumn{2}{l}{ Stressed/Unstressed } & & \multicolumn{2}{c}{ Unstressed/Stressed } & & \multicolumn{2}{c}{ Mixed } \\
\cline { 7 - 8 } \cline { 6 - 8 }$M$ & $S D$ & & $M$ & $S D$ & & $M$ & $S D$ \\
\hline 54.5 & $9.8^{*}$ & & 46.2 & $6.4^{*}$ & & 50.5 & 5.5 \\
\hline
\end{tabular}

*Significant $(p<.05)$ outcome of the one-sample $t$ test against chance $(50 \%)$. served in English infants (Jusczyk, Houston, \& Newsome, 1999), who have not yet learned to consider distributional patterns of phonemes and syllables as additional word boundary cues that may override metrical stress.

The finding that regular trochaic stress in the input aids recognition of bisyllabic Dutch nonwords supports our idea that Dutch diminutives can be beneficial for word segmentation. Because there are more monosyllabic than multisyllabic nouns in Dutch (Baayen, 1991), diminutivizing simplex forms considerably increases the frequency of trochaic patterns. It is nonetheless important to emphasize that stressed syllables are only probabilistic segmentation cues in Dutch, due to variability in word length and syllabic structure. Learners of Dutch must learn to recognize words with iambic, dactylic, and other stress patterns as well. Indeed, in some cases, diminutivization creates dactylic stress patterns, given trochaic simplex forms, thus complicating use of a metrical segmentation strategy. Given these limitations of metrical stress for word segmentation, we proceeded to assess whether enhanced invariance of word endings in diminutives also aids segmentation.

\section{EXPERIMENT 2}

In Experiment 2, we manipulated final syllable onsets and rhymes of trochaic nouns to explore the independent contributions of these two invariance components to incidental learning of word boundaries. We used the same methodology as that in Experiment 1, with the addition of a no-training condition in which the participants were presented with targets and foils without prior exposure to the speech stream, to determine whether performance in the forced choice task might be affected by a priori familiarity and the word-likeness of targets. For example, because vowel reduction commonly applies to word endings, targets ending in schwas may be perceived as more word-like in the absence of training, resulting in a main effect of rhyme invariance. Moreover, given that all the materials were trochees, a general advantage after training could simply indicate that the participants have used metrical segmentation to identify targets. Thus, the crucial question is whether benefits from ending invariance are larger after training, as indicated by interactions between training and ending invariance, which would confirm ending invariance as another segmentation cue extracted from the input.

\section{Method}

Participants. One hundred sixty-eight native speakers of English (110 women and $58 \mathrm{men}$; mean age, 21 years, range, 18-50 years) received course credit or $£ 4$ for participation. Forty-two were pseudorandomly assigned to each of four invariance conditions. Within each invariance condition, half of the participants were exposed to the speech stream before testing.

Materials. Six Dutch CCVC nonsense stems were created and combined with a second $\mathrm{C}(\mathrm{C}) \mathrm{V}$ syllable to systematically manipulate ending invariance (see Appendix B). The low onset/low rhyme invariance condition resembled Dutch bisyllabic simplex nouns by combining the stems with six different consonant/vowel combina- 
tions, which were all dissimilar from each other. Note that this condition was identical to the stressed/unstressed condition in Experiment 1 , providing a built-in replication. The low onset/high rhyme invariance condition resembled the degree of rhyme invariance of Dutch diminutives by combining the same second syllable consonant clusters with a schwa as the final vowel. The high onset/low rhyme invariance condition resembled the degree of onset invariance of Dutch diminutive affixes by combining the onset of the three most frequent allomorphs of the Dutch diminutive - namely, glide $/ \mathrm{j} /$ and the obstruent glide clusters $/ \mathrm{tj} /$ and $/ \mathrm{pj} /$ - and the full vowels used in the low onset/low rhyme invariance condition (Booij, 1995). Finally, the high onset/high rhyme invariance condition resembled the maximal ending invariance characteristic for Dutch diminutives by combining all stems with the three most frequent diminutive allomorphs: $-j e / \mathrm{j} ə /,-t j e / \mathrm{tj} /$, and $-\mathrm{pje} / \mathrm{pj}$ /.

The resulting bisyllabic strings were synthesized with trochaic stress, using the Dutch speech synthesizer CALIPSO. An approximately 6-min speech stream, comprising 100 repetitions of each target, was repeated three times for a total duration of $18 \mathrm{~min}$. For each condition, three different randomizations were used.

Foils for testing were created as in Experiment 1. Within each condition, target syllables were recombined so that the first syllables followed the second syllables. Test items were resynthesized using an unstressed/unstressed pattern. Creation of the test set containing the target-foil pairs was identical to that in Experiment 1.

Procedure. The procedure for the training condition was identical to that in Experiment 1. In the no-training condition, the participants were presented with the 72 target-foil test pairs in randomized order and were asked to indicate for each pair of strings, which string sounded more familiar, "like a sound they might have heard before," by pressing one of two buttons on the keyboard.

\section{Results and Discussion}

Table 2 presents the mean percentages of correct responses and the results of a one-sample $t$ test against chance $(50 \%)$. Performance was above chance in all the conditions except the two no-training low onset invariance conditions. Note that the $55 \%$ correct responses observed in the low onset/low rhyme invariance condition after training were virtually identical to the results for the stressed/unstressed condition in Experiment 1, showing stability in effect size for the metrical segmentation strategy. Moreover, the fact that, for this condition, performance was at chance in the absence of training supports our claim in Experiment 1 that stress regularities were detected during exposure to the speech stream.

Percentages of correct responses were submitted to a three-way ANOVA with training condition, onset invari- ance, and rhyme invariance as between-subjects factors. There were significant main effects of training condition $[F(1,160)=28.7, p<.001]$, onset invariance $[F(1,160)=$ $28.0, p<.001]$, and rhyme invariance $[F(1,160)=5.2$, $p<.05]$. The interaction between training condition and onset invariance was nearly significant $[F(1,160)=3.8$, $p=.05]$ and suggests that the benefit from affricates at final syllable onset was larger after training.

The main effects of the two invariance factors indicate that there were indeed a priori advantages for targets with more invariant word endings. For onset invariance, this was due to above-chance performance, because word-initial affricates rendered the test foils less wordlike. For rhyme invariance, schwa endings were selected above chance even without training, because they are familiar word endings for English speakers. The main effect of training indicates that performance in all the conditions improved after training, which could simply be due to metrical segmentation. Crucially, however, the nearly significant interaction between training and onset invariance suggests that exposure to the speech stream increased the participants' sensitivity to affricates as upcoming word boundary cues, over and above the notraining performance and the effects of regular stress. The lack of a similar interaction between training and rhyme invariance indicates that the benefit from schwa endings was less pronounced, due to their lesser perceptual salience and higher a priori familiarity.

Thus, the results showed that learners can extract invariance patterns from phonotactically unfamiliar input. Specifically, the participants learned that affricates at final-syllable onsets are valid cues for upcoming word boundaries. Given that affricates are a salient feature of Dutch diminutives, this supports the idea that diminutives can supply important distributional cues for word segmentation.

\section{GENERAL DISCUSSION}

The aim of this study was to examine word segmentation benefits from diminutives, a morphological derivation that tends to be pervasive in CDS (Brooks et al., 2002; Gillis, 1997, 1998; Jurafsky, 1996; Kempe, Brooks, \& Pirott, 2001). Diminutives amplify metrical information

Table 2

Mean Percentages of Correct Responses (With Standard Deviations) as a Function of Training Condition and Onset and Rhyme Invariance in Experiment 2

\begin{tabular}{|c|c|c|c|c|c|c|c|c|}
\hline \multirow[b]{4}{*}{ Condition } & \multicolumn{8}{|c|}{ Onset Invariance } \\
\hline & \multicolumn{4}{|c|}{ Low } & \multicolumn{4}{|c|}{ High } \\
\hline & \multicolumn{2}{|c|}{$\begin{array}{c}\text { Low Rhyme } \\
\text { Invariance } \\
\end{array}$} & \multicolumn{2}{|c|}{$\begin{array}{c}\text { High Rhyme } \\
\text { Invariance } \\
\end{array}$} & \multicolumn{2}{|c|}{$\begin{array}{l}\text { Low Rhyme } \\
\text { Invariance } \\
\end{array}$} & \multicolumn{2}{|c|}{$\begin{array}{c}\text { High Rhyme } \\
\text { Invariance }\end{array}$} \\
\hline & $M$ & $S D$ & $M$ & $S D$ & $M$ & $\overline{S D}$ & $M$ & $S D$ \\
\hline No Training & 49.1 & 8.7 & 52.8 & 9.9 & $55.2 *$ & 9.9 & $57.1^{*}$ & 11.9 \\
\hline Training & $55.1 *$ & 8.0 & $57.4 *$ & 8.9 & $64.3^{*}$ & 8.6 & $70.1^{*}$ & 13.2 \\
\hline
\end{tabular}


by regularizing the predominant stress pattern (Echols et al., 1997; Jusczyk, 1997), which, in the case of English and Dutch, is trochaic stress. Diminutives also supply distributional information by increasing invariance in word endings. Thus, diminutives may enhance sources of information that have been shown to be helpful segmentation cues for infants (Echols et al., 1997; Jusczyk, Houston, \& Newsome, 1999; Saffran et al., 1996).

Experiment 1 demonstrated above-chance word segmentation for trochaic and systematic missegmentation of iambic target strings, confirming that adult English speakers use stressed syllables as word onset cues even when processing phonotactically unfamiliar input. Thus, in English and Dutch, reliance on lexical stress appears to be of importance. This particular pattern is likely to be language specific and to occur in languages with lexical stress and a predominant trochaic bias, such as Dutch and English. It remains to be seen to what extent diminutives contribute to regularization of the dominant rhythmic patterns of other languages.

Experiment 2 demonstrated that word ending invariance aided segmentation over and above the benefits from trochaic stress. Note that ending invariance is not unique to diminutives but can be induced by any frequently appearing suffix. Thus, high-frequency inflectional or derivational suffixes, such as the English past tense $-e d$ or the progressive -ing, could serve as word segmentation cues. Although it remains to be investigated how the salience and frequency of different suffixes determines their usefulness as segmentation cues, it seems reasonable to assume that longer suffixes will act as more salient segmentation cues than shorter ones. In this sense, diminutives may provide an excellent and, perhaps, more universal source for invariance information, because, in many languages, diminutivization is achieved through suffixation, diminutive suffixes tend to comprise one or more syllables, and diminutives are used pervasively in CDS. Indeed, similar word segmentation experiments with materials that simulate the structure of Russian diminutives corroborate the ending invariance effect (Kempe, Brooks, \& Gillis, 2003). Together with the benefits of CDS in the acquisition of phonology (Kuhl et al., 1997), morphology (Kempe \& Brooks, 2001; Kempe, Brooks, Mironova, \& Fedorova, 2003), syntax (Fisher \& Tokura, 1996), and vocabulary (Golinkoff \& Alioto, 1995), this provides yet another example of how this speech register appears to be exquisitely tailored to the task of language learning.

\section{REFERENCES}

Aslin, R. N., Woodward, J. Z., LaMendola, N. P., \& Bever, T. G. (1996). Models of word segmentation in fluent maternal speech to infants. In J. L. Morgan \& K. Demuth (Eds.), Signal to syntax: Bootstrapping from speech to grammar in early acquisition (pp. 117-134). Mahwah, NJ: Erlbaum.

BAAYEN, R. H. (1991). De CELEX Lexicale Databank. Forum der Letteren, 32, 221-231.

BATCHELDER, E. O. (2002). Bootstrapping the lexicon: A computational model of infant speech segmentation. Cognition, $\mathbf{8 3}, \underline{167-206}$.
Boolu, G. (1995). The phonology of Dutch. Oxford: Oxford University Press.

Brent, M. R., \& CARTwright, T. A. (1996). Distributional regularity and phonotactic constraints are useful for segmentation. Cognition, $\underline{\mathbf{6 1}} 2$ 93-125.

BRENT, M. R., \& Siskind, J. M. (2001). The role of exposure to isolated words in early vocabulary development. Cognition, 81, B33-B44.

Brooks, P. J., Kempe, V., Fedorova, O., \& Mironova, N. (2002, July). Word play in child-directed speech: Diminutives as a window to noun morphology. Poster presented at the 9th Conference of the International Association for the Study of Child Language, Madison, WI.

Christiansen, M. H., Allen, J., \& Seidenberg, M. S. (1998). Learning to segment speech using multiple cues: A connectionist model. Language \& Cognitive Processes, 13, 221-268.

CUTLER, A. (1994). Segmentation problems, rhythmic solutions. Lingua, 92, 81-104.

CUTLER, A., \& Norris, D. G. (1988). The role of stressed syllables in segmentation for lexical access. Journal of Experimental Psychology: Human Perception \& Performance, 14, 113-121.

Dressler, W., \& Merlini BARBARESI, L. (1994). Morphopragmatics: Diminutives and intensifiers in Italian, German, and other languages. Berlin: Mouton.

Echols, C. H., Crowhurst, M. J., \& Childers, J. B. (1997). Perception of rhythmic units in speech by infants and adults. Journal of Memory \& Language, 36, 202-225.

FERNALD, A. (1989). Intonation and communicative intent in mothers' speech to infants: Is the melody the message? Child Development, 60, 1497-1510.

FISHER, C., \& TOKURA, H. (1996). Acoustic cues to grammatical structure in infant-directed speech: Cross-linguistic evidence. Child Development, 67, 3192-3218.

GILLIS, S. (1997). The acquisition of diminutives in Dutch. In W. Dressler (Ed.), Studies in pre- and protomorphology (pp. 165-179). Vienna: Verlag der Österreichischen Akademie der Wissenschaften.

GILLIS, S. (ED.) (1998). Studies in the acquisition of number and diminutive marking (Antwerp Papers in Linguistics 95). Antwerp: UIA.

Golinkoff, R. M., \& Alioto, A. (1995). Infant-directed speech facilitates lexical learning in adults hearing Chinese: Implications for language acquisition. Journal of Child Language, 22, 703-726.

Houston, D. M., JusczYK, P. W., KuiJPers, C., CoOlen, R., \& CutLER, A. (2000). Cross-language word segmentation by 9-month-olds. Psychonomic Bulletin \& Review, 7, 504-509.

JURAFSKY, D. (1996). Universal tendencies in the semantics of the diminutive. Language, 72, 533-578.

JuSCZYK, P. W. (1997). The discovery of spoken language. Cambridge, MA: MIT Press.

JusczyK, P. W., Hohne, E. A., \& Bauman, A. (1999). Infants' sensitivity to allophonic cues for word segmentation. Perception \& Psychophysics, 61, 1465-1476.

JusczYK, P. W., Houston, D. M., \& Newsome, M. (1999). The beginnings of word segmentation in English-learning infants. Cognitive Psychology, 39, 159-207.

KEMPE, V. (2004). [Unpublished data].

Kempe V., \& Brooks, P. J. (2001). The role of diminutives in Russian gender learning: Can child-directed speech facilitate the acquisition of inflectional morphology? Language Learning, 51, 221-256.

Kempe, V., Brooks, P. J., \& Gillis, S. (2003, November). Word segmentation benefits from diminutives: Cross-linguistic evidence. Poster presented at the 44th Annual Meeting of the Psychonomic Society, Vancouver, BC.

Kempe, V., Brooks, P. J., Mironova, N., \& Fedorova, O. (2003). Diminutivisation supports gender acquisition in Russian children. Journal of Child Language, 30, 1-15.

Kempe V., Brooks, P. J., \& Pirott, L. (2001). How can child-directed speech facilitate the acquisition of morphology? In M. Almgren, A. Barrena, M. J. Ezeizabarrena, I. Idiazabal, \& B. MacWhinney (Eds.), Research on child language acquisition: Proceedings of the 8th Conference of the International Association for the Study of Child Language (pp. 1237-1247). Medford, MA: Cascadilla.

Kuhl, P. K., Andruski, J. E., Chistovich, I. A., Chistovich, L. A., Kozhevnikova, E. V., Ryskina, V. L., Stolyarova, E. I., Sund- 
BERG, U., \& LACERDA, F. (1997). Cross-language analysis of phonetic units in language addressed to infants. Science, 277, 684-686.

MATTYS, S. L., \& JUSCZYK, P. W. (2001a). Do infants segment words or recurring contiguous patterns? Journal of Experimental Psychology: Human Perception \& Performance, 27, 644-655.

MATTYS, S. L., \& JusCZYK, P. W. (2001b). Phonotactic cues for segmentation of fluent speech by infants. Cognition, 78, 91-121.

Morgan, J. L. (1996). A rhythmic bias in preverbal speech segmentation. Journal of Memory \& Language, 35, 666-688.

Morgan, J. L., \& SaFFran, J. R. (1995). Emerging integration of sequential and suprasegmental information in preverbal speech segmentation. Child Development, 66, 911-936.

Saffran, J. R., Aslin, R. N., \& NeWPORT, E. L. (1996). Statistical learning by 8-month-olds. Science, 274, 1026-1928.

Saffran, J. R., Newport, E. L., Aslin, R. N., Tunick, R. A., \& BarRUECO, S. (1997). Incidental language learning: Listening (and learning) out of the corner of your ear. Psychological Science, $\mathbf{8}, 101-105$.

SluiJTer, A. M. C. (1995). Phonetic correlates of stress and accent (HIL Dissertation Series No. 15). The Hague: Holland Academic Graphics.

Taelman, H., \& Gillis, S. (2000) Gebruiken kinderen abstracte prosodische representaties? Een analyse van truncaties in het Maarten-corpus (Antwerp Papers in Linguistics 99). Antwerp: UIA.

\section{NOTES}

1. Iterative application of diminutive derivation, which is legal in Russian, may result in even longer strings, such as-chechka. The affricate $/ \mathrm{Ç} /$ or $/ \mathrm{t}_{\mathrm{L}} \mathrm{S} /$ is optional after some consonants.

2. There seems to be cross-linguistic similarity in the phonological structure of diminutives, because, in many languages, diminutive morphemes tend to contain palatal consonants and high vowels (Dressler \& Merlini Barbaresi, 1994).

3. The bisyllabic diminutive suffix - etje, which creates a dactylic, rather than a trochaic, pattern appears only in about $11 \%$ of diminutivized nouns (Gillis, 1997).

4. Although the pitch peaks of the first syllables of the test items were slightly higher, as compared with the second syllables, other acoustic parameters of metrical stress, such as intensity and within-syllable pitch differences, were somewhat greater, and vowel lengths were slightly longer in the second syllables, resulting in test items with an unstressed/unstressed pattern.

\section{Target Strings and Foils (and Their Phonemic IPA Transcriptions) Used During Training and Testing in Experiment 1, With Corresponding Pitch Peaks (in Hertz) of First and Second Syllables}

\begin{tabular}{|c|c|c|c|c|c|c|c|c|c|c|}
\hline & \multicolumn{10}{|c|}{ Stress Pattern } \\
\hline & \multicolumn{8}{|c|}{ Training } & \multirow{2}{*}{\multicolumn{2}{|c|}{$\begin{array}{c}\text { Testing: } \\
\text { Unstressed/ } \\
\text { Unstressed }\end{array}$}} \\
\hline & \multicolumn{2}{|c|}{$\begin{array}{c}\text { Stressed/ } \\
\text { Unstressed }\end{array}$} & \multicolumn{2}{|c|}{$\begin{array}{c}\text { Unstressed/ } \\
\text { Stressed }\end{array}$} & \multicolumn{2}{|c|}{ Mixed 1} & \multicolumn{2}{|c|}{ Mixed 2} & & \\
\hline & syll1 & syll2 & syll1 & syll2 & syll1 & syl12 & syll1 & syl12 & syll1 & syl12 \\
\hline \multicolumn{11}{|c|}{ Targets } \\
\hline schijvroo /s $\chi \varepsilon$ Ivro/ & 264 & 209 & 205 & 266 & 266 & 209 & 154 & 264 & 237 & 210 \\
\hline zweugloe /zwøylu/ & 265 & 216 & 247 & 268 & 223 & 263 & 265 & 230 & 237 & 207 \\
\hline chrapsee / $\chi$ rapse/ & 264 & 216 & 213 & 267 & 190 & 264 & 266 & 227 & 232 & 217 \\
\hline grieblau /yriblou/ & 263 & 246 & 215 & 265 & 191 & 264 & 264 & 252 & 234 & 220 \\
\hline$M$ & 264 & 221 & 222 & 266 & 232 & 243 & 233 & 250 & 236 & 212 \\
\hline \multicolumn{11}{|c|}{ Foils } \\
\hline vrooknui /vroknœy/ & & & & & & & & & 242 & 218 \\
\hline blauzweu /bløuzwø/ & & & & & & & & & 242 & 212 \\
\hline$M$ & & & & & & & & & 240 & 212 \\
\hline
\end{tabular}


APPENDIX B

Target Strings and Foils (and Their Phonemic IPA Transcriptions) Used in Experiment 2 With Corresponding Pitch Peaks (in Hertz) for the First and Second Syllables (Given in Parentheses)

\begin{tabular}{|c|c|c|c|c|}
\hline \multirow[b]{3}{*}{ Rhyme Invariance } & \multicolumn{4}{|c|}{ Onset Invariance } \\
\hline & \multicolumn{2}{|c|}{ Low } & \multicolumn{2}{|c|}{ High } \\
\hline & Targets & Foils & Targets & Foils \\
\hline \multirow[t]{12}{*}{ Low } & $\begin{array}{l}\text { knoochtie } \\
\text { /knoxti/ } \\
(264,200)\end{array}$ & $\begin{array}{l}\text { tieflijm } \\
\text { /tifleım/ }\end{array}$ & $\begin{array}{l}\text { knoochjie } \\
\text { /kno } \chi \mathrm{ji} / \\
(263,209)\end{array}$ & $\begin{array}{l}\text { jieflijm } \\
\text { /jifleım/ }\end{array}$ \\
\hline & $\begin{array}{l}(156,151) \\
\text { steefkeu }\end{array}$ & $\begin{array}{l}(150,153) \\
\text { keuvraul }\end{array}$ & $\begin{array}{l}(155,151) \\
\text { steefjeu }\end{array}$ & $\begin{array}{l}(151,152) \\
\text { jeuvraul }\end{array}$ \\
\hline & $\begin{array}{l}\text { /stefkø/ } \\
(265,208)\end{array}$ & /køvroul/ & $\begin{array}{l}\text { /stefjø/ } \\
(265,217)\end{array}$ & /jøvroul/ \\
\hline & $(152,152)$ & $(151,151)$ & $(156,151)$ & $(152,151)$ \\
\hline & $\begin{array}{l}\text { schraamloo } \\
\text { /s } \chi \text { ramlo/ } \\
(265,228)\end{array}$ & $\begin{array}{l}\text { loogluin } \\
\text { /loylœyn/ }\end{array}$ & $\begin{array}{l}\text { schraampjoo } \\
\text { /s } \chi \text { rampjo/ } \\
(265,211)\end{array}$ & $\begin{array}{l}\text { pjoogluin } \\
\text { /pjoylœyn/ }\end{array}$ \\
\hline & $(151,153)$ & $(154,154)$ & $(153,152)$ & $(152,151)$ \\
\hline & $\begin{array}{l}\text { flijmsaa } \\
\text { /fleımsa/ } \\
(266,218)\end{array}$ & $\begin{array}{l}\text { saaknooch } \\
\text { /sakno } \chi /\end{array}$ & $\begin{array}{l}\text { flijmpjaa } \\
\text { /fleımpja/ } \\
(265,207)\end{array}$ & $\begin{array}{l}\text { pjaaknooch } \\
\text { /pjakno } x /\end{array}$ \\
\hline & $(153,153)$ & $(152,152)$ & $(153,151)$ & $(154,152)$ \\
\hline & $\begin{array}{l}\text { gluinfee } \\
\text { /ylœynfe/ } \\
(266,213)\end{array}$ & $\begin{array}{l}\text { feeschraam } \\
\text { /fes } \chi \text { ram/ }\end{array}$ & $\begin{array}{l}\text { gluintjee } \\
\text { /ylœyntje/ } \\
(265,218)\end{array}$ & $\begin{array}{l}\text { tjeeschraam } \\
\text { ttjes } \chi \mathrm{ram} /\end{array}$ \\
\hline & $(154,153)$ & $(151,152)$ & $(154,151)$ & $(153,152)$ \\
\hline & $\begin{array}{l}\text { vraulpuu } \\
\text { /vroulpy/ } \\
(265,210)\end{array}$ & $\begin{array}{l}\text { puusteef } \\
\text { /pystef/ }\end{array}$ & $\begin{array}{l}\text { vraultjuu } \\
\text { /vroultjy/ } \\
(265,205)\end{array}$ & $\begin{array}{l}\text { tjuusteef } \\
\text { /tjystef/ }\end{array}$ \\
\hline & $(151,151)$ & $(151,152)$ & $(151,151)$ & $(151,153)$ \\
\hline Mean pitch peaks & $\begin{array}{l}(265,213) \\
(153,152)\end{array}$ & $(152,152)$ & $\begin{array}{l}(265,208) \\
(154,151)\end{array}$ & $(152,152)$ \\
\hline \multirow[t]{13}{*}{ High } & $\begin{array}{l}\text { knoochte } \\
\text { /knoxta/ } \\
(264,211)\end{array}$ & $\begin{array}{l}\text { teflijm } \\
\text { /təfleım/ }\end{array}$ & $\begin{array}{l}\text { knoochje } \\
\text { /kno } \chi \mathrm{j} ə / \\
(264,191)\end{array}$ & $\begin{array}{l}\text { jeflijm } \\
\text { /jofleım/ }\end{array}$ \\
\hline & steefke & kevraul & steefje & jevraul \\
\hline & $\begin{array}{l}\text { /stefkə/ } \\
(265,203)\end{array}$ & /kəvroul/ & $\begin{array}{l}\text { /stefja/ } \\
(264,210)\end{array}$ & /jəvrəul/ \\
\hline & $(151,151)$ & $(151,152)$ & $(151,151)$ & $(151,151)$ \\
\hline & $\begin{array}{l}\text { schraamle } \\
\text { /s } \chi \text { ramlə/ } \\
(264,229)\end{array}$ & $\begin{array}{l}\text { legluin } \\
\text { /loylœyn/ }\end{array}$ & $\begin{array}{l}\text { schraampje } \\
\text { /s } \chi \text { rampjə/ } \\
(265,202)\end{array}$ & $\begin{array}{l}\text { pjegluin } \\
\text { /pjoylœyn/ }\end{array}$ \\
\hline & $(151,153)$ & $(153,154)$ & $(153,151)$ & $(154,153)$ \\
\hline & $\begin{array}{l}\text { flijmse } \\
\text { /fleımsa/ } \\
(265,196)\end{array}$ & $\begin{array}{l}\text { seknooch } \\
\text { /səkno } \chi /\end{array}$ & $\begin{array}{l}\text { flijmpje } \\
\text { /fleImpjə/ } \\
(263,203)\end{array}$ & $\begin{array}{l}\text { pjeknooch } \\
/ \text { pjəkno } \chi /\end{array}$ \\
\hline & $(153,151)$ & $(153,152)$ & $(152,150)$ & $(151,152)$ \\
\hline & gluinfe & feschraam & gluintje & tjeschraam \\
\hline & $\begin{array}{l}\text { /ylœynfə/ } \\
(265,208)\end{array}$ & /fəs $\chi \mathrm{ram} /$ & $\begin{array}{l}\text { /ylœynt jə/ } \\
(266,203)\end{array}$ & $/ \mathrm{tj} \partial \mathrm{s} \chi \mathrm{ram} /$ \\
\hline & $(153,152)$ & $(152,152)$ & $(154,152)$ & $(151,152)$ \\
\hline & $\begin{array}{l}\text { vraulpe } \\
\text { /vroulpa/ } \\
(265,200)\end{array}$ & $\begin{array}{l}\text { pesteef } \\
\text { /pəstef/ }\end{array}$ & $\begin{array}{l}\text { vraultje } \\
\text { /vroult jə/ } \\
(265,204)\end{array}$ & $\begin{array}{l}\text { tjesteef } \\
\text { /tjostef/ }\end{array}$ \\
\hline & $(151,151)$ & $(151,152)$ & $(151,151)$ & $(153,152)$ \\
\hline \multirow[t]{2}{*}{ Mean pitch peaks } & $(265,211)$ & & $(265,202)$ & \\
\hline & $(152,151)$ & $(152,152)$ & $(152,151)$ & $(152,152)$ \\
\hline
\end{tabular}

Note-For the targets, the first two values refer to presentation during training, and the next two values to presentation during testing. 